DOI: 10.12797/Politeja.12.2015.36.10

Teresa SASIŃSKA-KLAS

Uniwersytet Jagielloński

uhsasins@cyfronet.krakow.pl

\title{
NAJNOWSZE WYZWANIA W METODOLOGII I BADANIACH W ZAKRESIE NAUK SPOŁECZNYCH
}

ABSTRACT The newest challenges in methodology and research in social sciences In the article the author analysed the newest challenges in the methodology, which are recognized and undertaken by researchers in social sciences, especially in the field of political science as a one of the subdisciplines. The article presents the results of the contribution of Research Committee 33 operating in the framework of the International Political Science Association to the methodological development of political science. In the framework of the newest methodological trends, which political scientist are transferring from other disciplines and adopting to the field it is necessary to point out: the grounded theory approach (GTA), case study research (CSR), surveys/public opinion polls, content analys is, context research, discourse analysis, comparative analysis and comparative methods.

Słowa kluczowe: nauki społeczne, metodologia, badania empiryczne, podejście teorii ugruntowanej, studia przypadku, badania sondażowe/badania opinii publicznej, badania tekstu, kontekstu, analiza dyskursywna, analiza porównawcza i metody porównawcze

Keywords: social science, methodology, empirical research, the grounded theory approach, case study research, sondague/ public opinion polls, content analysis, context research, discourse analysis, comparative analysis and comparative methods 
Celem nauk społecznych jest dążenie do „poznania natury w celu jej opanowania”. Z tego względu metodologia badań w obszarze nauk społecznych podlega nieustannym zmianom i modyfikacjom. Co powoduje ten stan permanentnej zmiany? Dynamika życia społecznego, coraz trudniejsza do zrozumienia, a jeszcze bardziej złożona, gdy to, co się zmienia na naszych oczach, bardzo szybko, głęboko, nieodwracalnie, zamierzamy poddać naukowemu oglądowi i rzetelnemu pomiarowi. Czy to w ogóle jest możliwe? Sięga się w analizie naukowej do coraz to nowszych ujęć badawczych, tworzy się nowe paradygmaty naukowe, poszerza się interdyscyplinarne podejście, prowadzi się badania zarówno ilościowe, jak i jakościowe itp., co zostanie przybliżone w przedstawionej analizie.

Wyzwania w metodologii nauk społecznych, zorientowanych dotychczas na poznanie kontekstu życia obywateli w społeczeństwie i jego organizacyjnych ram, pod wpływem zmian, jakie napotykamy w XXI w., sygnalizują z jednej strony, że barierą metodologiczną w tym obszarze działania naukowego są trudności w nadążaniu za zmianami, jakie dokonują się we współczesnych społeczeństwach, i w zrozumieniu, a następnie trafnym zdiagnozowaniu, co owe zmiany znaczą i jaki mogą przynieść skutek. Z drugiej strony dostrzega się na gruncie nauk społecznych upadek inżynierii społecznej, czy bardziej patetycznie to określając, śmierć „wielkich metanarracji”, które w przeszłości towarzyszyły myśleniu teoretycznemu i metodologicznemu zorientowanemu na zarządzanie „ładem socjalnym”. Studia nad polityką, kiedyś rozumiane jako „obiektywny opis" procesów zachodzących w rzeczywistości, współcześnie przypominają ustawiczną krytykę rzeczywistości. Czy to zmiana nieodwracalna? Trudno jednoznacznie rozstrzygnąć.

\section{NAUKI POLITYCZNE - QUO VADIS?}

Liczne studia i rozważania nad zdefiniowaniem pozycji i wyzwań w obszarze nauk politycznych są wyrazistym i charakterystycznym rysem tej dyscypliny. Gdy blisko sto lat temu, a dokładniej w 1921 r. politolog z University of Chicago, jeden z współtwórców szkoły chicagowskiej w naukach społecznych Charles Merriam prezentował na dorocznym zjeździe Amerykańskiego Towarzystwa Nauk Politycznych (American Political Science Association, APSA) referat zatytulowany The Present State of the Study of Politics, zaproponował w swoim wystąpieniu, by studia nad polityką stały się bardziej niż dotychczas naukowo zorientowane i zaczęły wykorzystywać analizę zmiennych behawioralnych/zachowaniowych oraz stosowały narzędzia matematyczne w prowadzonych badaniach empirycznych ${ }^{1}$. Propozycja Merriama spotkała się z pozytywnym oddźwiękiem i w tym kierunku sukcesywnie zaczęły podążać badania prowadzone na gruncie amerykańskiej, a także europejskiej politologii.

Ch. Merriam, H. Gosnell, The American Party System. An Introduction to the Study of Political Parties, New York 1922. 
Jednakże nie tylko Merriam odegrał istotną rolę w metodologicznym przeorientowaniu nauk politycznych. Należy także wymienić dwóch innych badaczy, którzy częściej są przywoływani w ramach pokrewnych dyscyplin z obszaru nauk społecznych. Chodzi tu o wpływ teoretyczny i inspiracje o charakterze metodologicznym zaproponowane przez amerykańskiego socjologa pochodzenia austriackiego (doktora nauk matematycznych) Paula Lazarsfelda², którego częściej przywołują socjologowie niż politologowie, oraz politologa i badacza propagandy Harolda Lasswella ${ }^{3}$, który - wydaje się to bezdyskusyjne - został niemal całkowicie inkorporowany do nauk o mediach, zwłaszcza gdy przedstawił w 1948 r. model analizy aktu komunikowania: Kto? - Co? - Jakim medium? - Do kogo? - Z jakim skutkiem? ? $^{4}$ Ten model aktu perswazyjnego do chwili obecnej stosowany jest przez badaczy w prowadzonych rozważaniach i badaniach nad komunikowaniem poprzez media.

To przesunięcie w metodologii i badaniach prowadzonych w ramach nauk politycznych nie dokonało się przy pełnej aprobacie środowiska naukowego i w sposób aksamitnys. Towarzyszyły temu przeorientowywaniu się nauk politycznych w stronę szerszej perspektywy o charakterze teoretycznym i metodologicznym liczne opinie krytyczne i sceptycyzm co do tego, czy uda się zorientować nauki polityczne w kierunku nauk stosowanych ${ }^{6}$. I do dzisiaj ten spór się toczy, choć na znacznie bardziej zaawansowanym poziomie ${ }^{7}$.

Od momentu, gdy wymienieni wyżej, jak i wielu innych niewspomnianych z imienia i nazwiska twórczych pionierów w zakresie metodologii w naukach społecznych podjęło trud poszerzenia pola analizy metodologicznej oraz zakresu problematyki badawczej, do chwili obecnej upłynęło dużo czasu i dokonało się wiele zmian, jeśli idzie o podejście metodologiczne rozwijane na gruncie nauk społecznych. Niemniej przedmiotem szczegółowego zainteresowania w poniższej analizie będzie jedna z dyscyplin z obszaru nauk społecznych, jaką są nauki polityczne, i na niej zostanie głównie skupiona dalsza uwaga.

Podejmowane rozważania, publiczne deklaracje dotyczące tego, czym ma zajmować się politologia jako dyscyplina naukowa, bardziej zmierzały w ostatnich kilkudziesięciu

P. Lazarsfeld, B. Berelson, H. Gaudet, The People's Choice. How the Voter Makes Up his Mind in a Presidential Campaign, New York 1944.

3 H. Lasswell, The Structure and Function of Communication in Society, [w:] The Communication of Ideas. A Series of Addresses, red. L. Bryson, New York 1948, s. 32-51, Religion and Civilization Series. Zob. też: Lasswell H. i in., Language of Politics. Studies in Quantitative Semantics, New York 1949.

4 H. Lasswell, The Structure..., s. 37.

5 Na ten temat zob. m.in.: D. Easton, The Political System. An Inquiry into the State of Political Science, New York 1953.

6 M. Dogan, Political Science and the Other Social Sciences, [w:] A New Handbook of Political Science, red. R. Goodin, H.-D. Klingemann, Oxford 1996, s. 97-130.

Zob. rozważania Jana van Dijka w pracy: Digital Democracy. Issues of Theory and Practice, red. K. Hacker, J. van Dijk, London 2000, zwt. Widening Information Gaps and Policies of Prevention, a także Models of Democracy and Concepts of Communication, s. 30-53. Na ten temat pisze krytycznie także kanadyjski politolog John E. Trent: tenże, Should Political Science be More Relevant? An Empirical and Critical Analysis of the Discipline, „European Political Science” 2011, Vol. 10, nr 2, s. 191-209, [online] http://dx.doi.org/10.1057/eps.2010.65. 
latach do tego, by określić, jaki powinien być zakres i profil zainteresowań w jej obrębie, niż jakie założenia metodologiczne winne przyświecać poszerzającej się perspektywie analitycznej. Kwestie natury metodologicznej rozpoczynające się od stawiania podstawowych pytań określających status danej dyscypliny, takich jak pytania typu: dlaczego?, podejmowane były stosunkowo rzadko.

Nie można także wyraźnie wskazać i stwierdzić, że osiągnięto wiele sukcesów we wzajemnym zbliżeniu nauk politycznych jako dyscypliny naukowej i - szeroko ujmowanej - praktyki politycznej czy w zacieśnianiu się powiązań pomiędzy politologami a politykami w procesie poznawania rzeczywistości politycznej ${ }^{8}$. Nie dotyczy to tylko Polski jako młodego demokratycznego państwa i jego obywateli, choć takie próby były wielokrotnie podejmowane z bardzo ograniczonym rezultatem, także z inicjatywy Polskiego Towarzystwa Nauk Politycznych - organizacji zrzeszającej znaczącą liczbę zawodowo czynnych politologów w kraju.

Na podobne prawidłowości i ich skromne rezultaty można wskazać także w dojrzałych demokracjach, które w większości krajów do tej pory również nie wypracowały efektywnych standardów kooperacji i współdziałania pomiędzy teoretykami a praktykami w zakresie analizy sfery polityki i doradztwa w tym zakresie?.

\section{WKŁAD RESEARCH COMMITTEE 33: THE STUDY OF POLITICAL SCIENCE AS A DISCIPLINE IPSA W ROZWÓJ METODOLOGICZNY NAUK POLITYCZNYCH}

Przez wiele lat zagadnienia natury metodologicznej coraz wyraźniej traciły na ważności, coraz częściej były marginalizowane, a nawet można stwierdzić, że zaniedbywane w całościowych rozważaniach prowadzonych na gruncie nauk społecznych. Dotyczyło to takich dyscyplin w ramach nauk społecznych, jak: nauki polityczne, ekonomia, w mniejszym stopniu socjologia, psychologia, historia, które wcześniej wniosły znaczący wkład w ich rozwój. Dominowało podejście ilościowe w prowadzonych badaniach empirycznych, natomiast podejście jakościowe traktowano jako przestarzałe i niewystarczające do orzekania o istocie empirycznego poznania rzeczywistości. Od pewnego czasu sytuacja uległa zmianie i należy stwierdzić, że zmierza w korzystnym - dla dalszego rozwoju nauk społecznych - kierunku.

Należy zauważyć od blisko trzydziestu lat - z różnym natężeniem - powrót zainteresowań naukowych zorientowanych na metodologiczne osadzenie i „obudowanie”, jak teżzintensyfikowanie się rozważań, analiz o charakterze teoretyczno-metodologicznym, a także badań empirycznych prowadzonych w obrębie nauk politycznych. Prowadzi się na coraz szerszą skalę badania nie tylko o charakterze poznawczym, lecz także o cha-

Pisze o tym John E. Trent w referacie Seeking a New Political Studies Paradigm wygłoszonym w ramach "International Workshop on Study and Research of Political Science in a Comparative Perspective", Mexico City, 7-8 XI 2013.

9 Zob. na ten temat: Power. State of the Art, red. M. Haugaard, K. Ryan, Opladen 2012. 
rakterze użytkowym, diagnostycznym. Stwierdzić należy, że od kilkunastu lat prowadzi się w naszym kraju coraz więcej badań społecznych o charakterze stosowanym, instytucje życia publicznego zamawiają bowiem w różnych ośrodkach badawczych, także w instytucjach prowadzących badania opinii publicznej, tematy do realizacji, diagnozy, ekspertyzy itp., których wyniki wykorzystuje się następnie w procesie podejmowania decyzji dotyczących np. prowadzenia skuteczniejszych kampanii wyborczych, rozpoznawania oczekiwań społecznych, pozyskiwania poparcia społecznego, procesu sprawowania władzy, poczucia bezpieczeństwa/poczucia zagrożenia obywateli np. terroryzmem, komunikacji politycznej pomiędzy władzą a obywatelami, stosunku obywateli do innych narodowości, do zaistniałych konfliktów, np. militarnych, itp. To tylko niektóre, przykładowo wymienione zagadnienia i tematy badawcze realizowane dla potrzeb praktyki. Pełna lista jest znacznie bardziej rozbudowana i wręcz niemożliwa do całościowego skompletowania.

Od końca lat 70., a wyraźnie w latach 80. XX w., rozpoczyna się w politologii zauważalne ożywienie zainteresowania rozważaniami, dyskusjami i sporami natury metodologicznej oraz próba ich przełożenia i zweryfikowania w podejmowanych na coraz szerszą skalę badaniach empirycznych prowadzonych w obrębie nauk politycznych. Taka sytuacja występuje także obecnie, czyli mamy współcześnie do czynienia z kontynuacją, a równocześnie wyraźnym trendem wzrostowym zainteresowań i rozważań o charakterze metodologicznym podejmowanych w rozszerzającym się polu zakresowym nauk politycznych oraz dyscyplin z pogranicza, takich jak: stosunki międzynarodowe, nauki o bezpieczeństwie, studia regionalne (area studies), nauki o mediach itd. Badania skupiają przedstawicieli różnych dyscyplin w obszarze nauk społecznych i z definicji stają się w coraz większym stopniu badaniami multidyscyplinarnymi. Dla przykładu studia regionalne nowej generacji obnażyły sztuczność podziałów instytucjonalnych i tradycyjnego rozgraniczenia badań na politologiczne, socjologiczne, psychologiczne itd. w ramach nauk społecznych. Okazało się, że dopiero przyjęcie podejścia multidyscyplinarnego daje interesujące poznawczo rezultaty, a nie podtrzymywanie starych, schematycznych i niewystarczających - dla pełnego rozpoznania badanych problemów społeczno-politycznych - podziałów.

Równolegle w środowisku politologicznym naszego kraju toczy się coraz bardziej zaawansowana i zaangażowana dyskusja na temat statusu naukowego i tożsamości dyscypliny, czego wyrazem są stanowiska i opinie, często o bardzo emocjonalnym wydźwięku, prezentowane przez przedstawicieli środowiska naukowego na różnych forach dyskusyjnych, konferencjach naukowych itp.

Poniżej nasza uwaga zostanie skupiona na analizie tego, co nowego, inspirującego dostrzega się w badaniu rzeczywistości społecznej i procesów politycznych występujących w jej obrębie, a co równocześnie wskazuje na nowe teoretyczne oraz metodologiczne otwarcie w obrębie politologii.

Źródeł informacji na ten temat należy upatrywać w rozważaniach natury metodologicznej inspirowanych przez Komitet Badawczy nr 33: Studia w zakresie nauk politycznych jako dyscyplina Międzynarodowego Towarzystwa Nauk Politycznych (Research Committee 33: The Study of Political Science as a Discipline, International 
Political Science Association) w okresie ostatnich blisko trzydziestu lat, które odbiły się głośnym echem i zostały podjęte oraz pogłębione przez politologów badających rzeczywistość społeczną i procesy polityczne w różnych regionach świata, a krócej: w globalnej wiosce ${ }^{10}$, sięgając do metafory zaproponowanej przez Marshalla McLuhana, badacza środków komunikowania masowego z University of Toronto w połowie lat 60. XX w.

Kierowany przez wiele lat i działający bardzo dynamicznie pod kierunkiem kanadyjskiego politologa z University of Ottawa Johna Trenta, we współpracy z Michaelem Steinem, Research Committee 33, funkcjonujący formalnie w obrębie IPSA, podją się zadania zdiagnozowania stanu metodologicznego i badawczego dorobku dyscypliny, jaką są nauki polityczne w wymiarze globalnym. Rezultatem tych zabiegów jest publikacja dwunastu pozycji książkowych (w okresie od 2006 do 2012 r.), które ukazały się w języku angielskim w ramach serii wydawniczej The World Political Science: The Development of the Discipline. Opublikowane tomy rozważań tematycznie objęty analizę stopnia zaawansowania metodologicznego oraz specyfikę badawczą nauk politycznych realizowaną na wszystkich kontynentach świata w perspektywie zarówno historycznej, jak i współczesnej. To ogromnie znaczący wkład źródłowy w diagnozę stanu rozwoju tej dyscypliny w wymiarze globalnym. To wartościowe źródło wiedzy o tym, jak rozpoczynał się proces rozwoju dyscypliny w różnych regionach świata, jak nawzajem wpływały na siebie różne nurty teoretyczne i trendy badawcze ukształtowane w ramach nauk społecznych, które - następnie - inspirowały określone kierunki rozwoju i obszary zainteresowań, stymulując politologów skupionych w różnych ośrodkach akademickich na świecie do podjęcia studiów i rozważań oraz badań nad różnymi aspektami funkcjonowania społeczeństwa i jego instytucji w sferze publicznej.

Rezultaty tej pionierskiej aktywności są dostępne w formie wspomnianych wyżej dwunastu publikacji książkowych, które ukazały się nakładem niemieckiej oficyny wydawniczej Barbara Budrich Publishers usytuowanej w Opladen w Niemczech i kierowanej przez właścicielkę wydawnictwa, czyli wymienioną w nazwie Barbarę Budrich. Zainteresowanych tematyką opublikowanych prac odesłać należy do strony internetowej wydawnictwa ${ }^{11}$, gdzie można znaleźć więcej szczegółowych informacji na ten temat.

Odnosząc się bardziej wnikliwie do działalności Komitetu Badawczego nr 33 w ramach Międzynarodowego Towarzystwa Nauk Politycznych dotyczącej koordynacji wysiłków naukowych na rzecz określenia statusu naukowego i metodologicznego politologii jako dyscypliny, należy podkreślić jego szczególnie znaczącą - w wymiarze globalnym - rolę integracyjną na rzecz jej rozwoju. Aktualnie spośród pięćdziesięciu komitetów badawczych działających w ramach IPSA Research Committee 33 wyróżnia się w sposób szczególny dorobkiem naukowym, jak i integracyjnym na rzecz rozwoju dyscypliny, jaką są nauki polityczne. Jak do tego doszło?

10 Pojęcie globalnej wioski $z$ definiowane zostało przez Marshalla McLuhana jako metaforyczne określenie naszej planety, która od czasu pojawienia się telegrafu zostata pod wptywem elektryczności zredukowana do rozmiarów wioski - $i$ to we wszystkich aspektach swojego funkcjonowania i organizacji spotecznej M. McLuhan, Zrozumieć media. Przedtużenia cztowieka, przeł. N. Szczucka, Warszawa 2004, s. 458.

Bundich-Verlag, [online] www.budrich-verlag.de. 
W 1982 r. z inicjatywy dwóch kanadyjskich politologów: Johna E. Trenta z University of Ottawa i Michaela B. Steina z MacMaster University zorganizowano w trakcie XII Światowego Kongresu IPSA w Rio de Janeiro (Brazylia) seminarium, a w jego następstwie powołano grupę studialną podejmującą - po raz pierwszy w działalności IPSA - kwestie metodologiczne związane z rozwojem tej dyscypliny. Stworzona wówczas Study Group on the Comparative Sociology of Political Science podjęła pierwsze działania mające na celu zdiagnozowanie stanu zaawansowania metodologicznego i stopnia badawczego rozwoju tej, ciągle młodej, dyscypliny naukowej funkcjonującej na gruncie nauk społecznych. W 1985 r. na konferencji w Espoo (Finlandia) zorganizowanej wspólnie przez Finnish Political Science Association oraz IPSA na temat „Development and Institutionalization of Political Science: Center-Periphery and Other Crucial Concepts" z inicjatywy amerykańskiego politologa Davida Eastona z University of California (Irvine) powołano International Committee for the Study on Development and Institutionalization of Political Science.

Cztery lata później, w 1989 r., Study Group on the Comparative Sociology of Political Science, kierowana przez Johna Trenta i Michaela B. Steina, oraz International Committee for the Study Group on Development and Institutionalization of Political Science, kierowany przez Davida Eastona złożyły do Komitetu Wykonawczego (Executive Committee) IPSA wspólny wniosek o powołanie odrębnego Komitetu Badawczego w ramach IPSA, który skupiłby się w swoich działaniach na rozwoju metodologicznym politologii jako ciągle niewystarczająco rozwiniętej w tym zakresie dyscypliny funkcjonującej w obrębie nauk społecznych. Inicjatywa ta została zaaprobowana przez władze wykonawcze IPSA i w 1991 r. na kolejnym, XV Kongresie Światowym IPSA w Buenos Aires rozpoczął działalność Research Committee 33: The Study of Political Science as a Discipline. Pracom Komitetu w jego pierwszym stadium działania przewodniczyli: David Easton z University of California (Irvine) oraz John G. Gunnell z SUNY at Albany, wnosząc swoje doświadczenie i inspiracje natury metodologicznej przedstawiane w wielu pracach i rozważaniach naukowych. Także wkład naukowy i aktywność w wymiarze integracyjnym Johna E. Trenta oraz Michaela B. Steina z Kanady zasługują na szczególne uznanie, odgrywają oni bowiem w dalszym ciągu ważną rolę w stymulowaniu i podejmowaniu rozważań natury metodologicznej, zwłaszcza przez młode pokolenia politologów, służących rozwojowi politologii w jej globalnym wymiarze.

W ciągu tych dwudziestu czterech lat działalności Research Committee 33 wielu politologów z różnych regionów świata aktywnie włączyło się w jego działalność. Byli to m.in., poza wcześniej wymienionymi Johnem E. Trentem, Michaelem B. Steinem z Kanady, Davidem Eastonem i Johnem G. Gunnellem z USA, Mattei Dogan z CNRS w Paryżu, Thibaud Boncourt z Institut d'etudes politiques de Bordeaux (Francja), Michael Crozier z University of Melbourne (Australia), Hans-Dieter Kilngemann, Dirk Berg-Schlosser, Rainer Eisfeld z Niemiec, Erkki Berndtson z University of Helsinki - aktywny od samego początku w pracach na rzecz powstania komitetu badawczego, obecnie jego przewodniczący - i wielu, wielu innych uczonych i badaczy ${ }^{12}$.

12 Więcej na temat działalności RC 33 można przeczytać na stronie IPSA: http://rc33.ipsa.org. 
Dotychczas aktywny udział w działaniach inicjowanych przez Research Committee 33 wzięło sześciu reprezentantów politologii z regionu Europy Środkowo-Wschodniej: Jan Holzer z Uniwersytetu Masaryka w Brnie (Republika Czeska), Lucjana Alexandra Ghica i Fred Mahler z Bukaresztu (Rumunia), Mijat Damjanovic z Uniwersytetu w Belgradzie (Serbia), Igor Lukšič z University of Ljubljana (Słowenia) oraz Teresa Sasińska-Klas z Uniwersytetu Jagiellońskiego. Podkreślić należy, że znaczącą aktywność wnoszą w rozwój naukowy Komitetu politologowie rosyjscy, zwłaszcza wymienić należy prof. Olgę Malinową z Rosyjskiej Akademii Nauk w Moskwie. Wielu politologów z Europy Środkowo-Wschodniej wniosło znaczący wkład w przygotowanie rozdziałów do publikacji wydanej z inicjatywy Komitetu pod redakcją Rainera Eisfelda i Leslie Pala prezentującej stan rozwoju teoretycznego, kierunki badań i założenia metodologiczne stosowane w rozwijaniu politologii w krajach tej części Europy ${ }^{13}$.

Reasumując, w globalnym wymiarze poziom instytucjonalizacji działań na rzecz rozwoju podejścia metodologicznego w obrębie nauk politycznych ocenić należy pozytywnie. W ciągu dwudziestu czterech lat udało się wypracować ramy instytucjonalne działań w tym zakresie, zainteresować badaczy z różnych regionów świata podjęciem prac i studiów naukowych w obrębie metodologii nauk społecznych, które pozwoliłyby na ich wykorzystanie do rozwoju jednej z nauk społecznych, jaką są nauki polityczne.

Jakie zagadnienia i tematy natury metodologicznej podejmowane były przez IPSA w okresie poprzedzającym powstanie RC 33: The Study of Political Science as a Discipline, a następnie po jego powstaniu w 1991 r. w trakcie światowych Kongresów IPSA, czyli począwszy od 1985 r. do chwili obecnej? Wymienić należy w chronologicznej kolejności tematy paneli metodologicznych, jakie zostały podjęte w ramach zainicjowanych kierunków rozważań i studiów o charakterze metodologicznym przez International Political Science Association, które ukierunkowały tematycznie działalność badawczą nauk politycznych w przedmiotowym zakresie.

Oto one:

1. XIII Congress IPSA, Paryż (Francja), 1985

Panel metodologiczny: Changing Paradigms in Political Science and their International/National Societal Linkages

2. XIV Congress IPSA, Waszyngton, D.C. (USA), 1988

Panel metodologiczny: Impact of the Political Context on the Development of Political Science in Different Societies

3. XV Congress IPSA, Buenos Aires (Argentyna), 1991

Research Committee 33: The Study of Political Science as a Discipline

Panel 1. From Post-Behavioralism to Post-Modernism

13 Political Science in Central-East Europe. Diversity and Convergence, red. R. Eisfeld, L. Pal, OpladenFarmington Hills 2010. 
Panel 2. The Implications for Political Science of the Collapse of Communism in Eastern Europe and the Former USSR

4. XVI Congress IPSA, Berlin (Niemcy), 1994

Research Committee 33: The Study of Political Science as a Discipline

Panel 1. Conceptual Development and Genealogy in Political Science

Panel 2. The Implications for Political Science of the Collapse of Communism in Eastern Europe and the Former USSR

5. XVII Congress IPSA, Seul (Korea Południowa), 1997

Research Committee 33: The Study of Political Science as a Discipline

Panel 1. Creativity in Political Science: Alternatives to Marginality

Panel 2. Conceptual Development in Political Science

6. XVIII Congress IPSA, Quebec (Kanada), 2000

Research Committee 33: The Study of Political Science as a Discipline

Panel 1. The Universalization and Indigenization of Political Science and Its Concepts

Panel 2. The Relevance of the Study of the Discipline to the Practice of Political Science Panel 3. Women and Politics: The State of the Discipline and Other Reflections

7. XIX Congress IPSA, Durban (RPA), 2003

Research Committee 33: The Study of Political Science as a Discipline

Panel 1. Is Political Science Still Considered to be the American Science of Politics?

8. XX Congress IPSA, Fukuoka (Japonia), 2006

Research Committee 33: The Study of Political Science as a Discipline

Panel 1. Is There a Genuinely International Discipline of Political Science? An Overview of Recent Global Trends and Development

Panel 2. Women and Politics: The State of the Discipline and Other Reflections

9. XXI Congress IPSA, Santiago (Chile), 2009

Research Committee 33: The Study of Political Science as a Discipline

Panel 1. Education Policies and the Development of Political Science

Panel 2. The Development of Political Science in Latin America and the Arab World

Panel 3. Nonkilling Political Science: A Critical Evaluation

10. XXII Congress IPSA, Madryt (Hiszpania), 2012

Research Committee 33: The Study of Political Science as a Discipline

Panel 1. Political Science in Latin America

Panel 2. The Globalization of Political Science: Whatever Happened to National Traditions? 
Panel 3. The Fragmentation of Political Science as a Discipline

Panel 4. Roundtable on Gender and Politics: State of the Discipline (wspólny panel z RC 19: Gender Politics and Policy)

11. XXIII Congress IPSA, Montreal (Kanada), 2014

Research Committee 33: The Study of Political Science as a Discipline

Panel 1. Political Science in the Public Space: Comparing Experiences and Contexts Panel 2. Political Science in Latin America

Panel 3. Paradigms and Historiography in Political Studies

Special Session. Political Science: Current Performance and Future Strengths

Wspólny panel z Research Committee 31: Political Philosophy i Research Committee 32: Public Policy and Administration

część I: Governance, the State and Making Sense of Governing częśc II: Governance, the State and Making Sense of Governing: Governing Up, Governing Down

Wyraźnie da się zauważyć w przytoczonej liście tematów głównych obrad RC 33 i poszczególnych, starannie dobranych tematycznie paneli poszerzanie się - w ciągu ostatnich trzydziestu lat, które upłynęły od momentu zakreślenia przez IPSA - pola analizy metodologicznej, zorientowanego na osobliwości i zarazem specyfikę nauk politycznych jako jednej z dyscyplin mieszczących się w ramach nauk społecznych. I trend ten utrzymuje się nieprzerwanie do chwili obecnej. Co więcej, przybywa tematów i propozycji do analizy odnoszących się także do najnowszych wątków badawczych podejmowanych $\mathrm{w}$ różnych regionach świata z coraz silniejszym uwzględnieniem kontekstu geograficzno-kulturowego, co w przeszłości nie było obecne w tak znaczącym stopniu.

\section{WYZWANIA BADAWCZE WE WSPÓŁCZESNEJ POLITOLOGII}

Podejmowane z inicjatywy IPSA aktywne działania związane z potrzebą organizowania seminariów o charakterze metodologicznym adresowanych głównie do młodych politologów, którymi od 2009 r. kieruje prof. Dirk Berg-Schlosser, nakreślają nowe wyzwania w zakresie nauk politycznych. Aktualnie w polu zainteresowania nauk politycznych wyodrębnić można trzy zagadnienia teoretyczno-metodologiczne, które wywierają wpływ na kontekst prowadzonych rozważań.

Pierwsze dotyczy relacji badacz-badania. Przyjmuje się, że należy pozbyć się złudnego, archaicznego założenia, że możliwa jest neutralność badaczy w odniesieniu do badanych przez nich obiektów. Badacz w obszarze nauk społecznych uwikłany jest w kontekst sytuacji, w ramach której prowadzi badania, i stanowi to niekwestionowany fakt społeczny.

Drugi problem związany jest z koniecznością uwzględniania w prowadzonych analizach czasu i przestrzeni jako zmiennych istotnych 
dla rezultatu wyników badań. Niemożliwe jest generalizowanie uzyskanych danych bez ich odniesienia do czasu, w którym zostały one zebrane, oraz miejsca, w którym zaistniały badane fakty i wydarzenia.

Trzeci problem wiąże się z koniecznością przezwyciężenia ciągle obecnych $\mathrm{w}$ myśleniu wielu przedstawicieli nauk społecznych, w tym nauk politycznych, sztucznych podziałów powstałych w klimacie dziewiętnastowiecznych sporów i dysput naukowych między rzekomo autonomicznymi sferami: polityczną, społeczną i ekonomiczną ${ }^{14}$. Obserwacja życia społecznego pokazuje, że te sfery przenikają się nawzajem.

Nawiązując do inicjatywy IPSA w zakresie otwierania się na nowe wyzwania natury metodologicznej i inicjatywy badawcze podejmowane w tym zakresie, wskazać należy, że aktualnie do takich wyzwań, wokół których toczy się w środowisku politologów $\mathrm{w}$ świecie dyskusja nad ich wdrożeniem i zaadoptowaniem dla potrzeb prowadzonych badań naukowych na gruncie nauk politycznych, zaliczyć należy pięć kategorii tematycznych wymagających starannego metodologicznego osadzenia. Są to:

1. Metodologia teorii ugruntowanej, MTU (The Grounded Theory Approach, GTA), która coraz częściej staje się jedną z najczęściej stosowanych strategii w badaniach o charakterze jakościowym. Główne założenia tej metody opracowane zostały wprawdzie dość dawno temu, pod koniec lat $60 . \mathrm{XX} \mathrm{w.}{ }^{15}$, lecz z biegiem lat były one sukcesywnie rozwijane i poszerzały zakresowo zaproponowaną strategię badawczą ${ }^{16}$. Zainteresowanie środowiska badaczy nauk społecznych tym podejściem metodologicznym nastąpiło jednak znacznie później i należy je uznać za otwarte i na początku drogi, na której mogą powstać teorie w oparciu o dane empiryczne. W polskiej literaturze przedmiotu teorię ugruntowaną przybliżył badaczom w obszarze nauk społecznych Marek Gorzko, socjolog z Uniwersytetu Szczecińskiego ${ }^{17}$. Przyjmuje się, że teoria ugruntowana jest „rodziną metod”, charakteryzuje ją zróżnicowanie metodologiczne w obrębie podejścia teoretycznego ${ }^{18}$. Problemy, wokół których ogniskuje się dyskusja nad zakresem metodologicznym teorii ugruntowanej, dotyczą następujących kwestii, które - zdaniem Anthony Bryanta i Kathy Charmaz - wymagają rozstrzygnięcia:

- co jest ugruntowane (kategorie, pojeccia czy teoria, co oznacza ugruntowanie?),

- problem danych,

- indukcja, dedukcja-abdukcja,

14 Wyzwania wobec nauk spotecznych u progu XXI wieku, oprac. A. Flis, przeł. B. Lessaer, Kraków 1999.

15 B.G. Glaser, A.L. Strauss, The Discovery of Grounded Theory. Strategies for Qualitative Research, Chicago 1967, Observations (wyd. pol. Odkrywanie teorii ugruntowanej. Strategie badania jakościowego, przeł. M. Gorzko, Kraków 2009, Wspótczesne Teorie Socjologiczne, 6).

16 J. Strubing, Research as Pragmatic-Solving: the Pragmatists Roots of Empirically-Grounded Theorizing, [w:] The SAGE Handbook of Grounded Theory, red. A. Bryant, K. Charmaz, Los Angeles-London 2007.

17 M. Gorzko, Procedury i emergencja. O metodologii klasycznych odmian teorii ugruntowanej, Szczecin 2008, Rozprawy i Studia Uniwersytetu Szczecińskiego, t. 693.

18 Więcej na ten temat zob.: tenże, Teoria ugruntowana jako „rodzina metod”?, „Opuscula Sociologica” 2013, nr 4, s. 5-16. 
- problem wrá̇liwości teoretycznej (simple yet skilful),

- kody teoretyczne, paradygmat kodowania,

- problem weryfikacji,

- wykorzystanie literatury przedmiotu,

- zwiazek metodologii teorii ugruntowanej z interakcjonizmem symbolicznym,

- diagramy ${ }^{19}$.

Metodologia teorii ugruntowanej jest przykładem strategii badawczo-analitycznej, która koncentruje się na generowaniu pojęć, hipotez i teorii powstałych w oparciu o dane empiryczne. Metodologia ta zakłada, że badanie jest procesem, w ramach którego badacz wielokrotnie powraca do dalszego zbierania danych i pogłębiania analizy. Spowodowane jest to tym, że po zebraniu założonych, niezbędnych do analizy tematu danych badacz stawia kolejne pytania badawcze, co wymaga kontynuacji procesu badawczego dotyczącego danego tematu. Ten proces powrotu do badania może być wielokrotnie powtarzany, jego celem jest osiągnięcie satysfakcjonującego poziomu nasycenia badanych kategorii. Rozstrzygnięcie o wystarczającym stopniu nasycenia oznacza, że nie zachodzi dla badanego tematu konieczność dalszego tworzenia konceptualnych kategorii i można przystępować do jego opracowania pojęciowego oraz zdefiniowania ${ }^{20}$.

Przedstawiciele teorii ugruntowanej przyjmują założenie, że teoria wyłania się z danych. Nie dokonuje się to w prosty sposób. Jednakże, gdy badacz zachowuje otwartość i wnikliwość analityczną w toku zbierania danych (np. w trakcie kodowania zebranego materiału), może stosować w sposób ciągły technikę porównawczą i dokonywać teoretycznie uzasadnionego dalszego pobierania próbek do badań tak, aby osiągnąć wysokie nasycenie badanymi kategoriami analitycznymi. Zdaniem Kathy Charmaz, jednej z głównych przedstawicielek tego nurtu teoretycznego, teoria nie powstaje i nie rozwija się jako niezależna od wysiłków badacza istotnośćc ${ }^{21}$. Zakłada ona, że to badacz i przyjęta przez niego perspektywa metateoretyczna wywierają wpływ na to, w jaki sposób i przy użyciu jakich instrumentów dokonuje się uzyskiwanie danych, a następnie konstruowanie kategorii analitycznych. Oznacza to, że nie istnieje neutralność badacza, pozostaje on bowiem w relacji do czasu, w którym prowadzi badanie naukowe, jak i podłoża historycznego, którego badanie dotyczy, i z tego względu ustalenia oraz dokonywane przez niego rozstrzygnięcia mają charakter kontekstualny i nawiązują do dyskursu naukowego, w ramach którego rozważane jest badane zagadnienia i w którym to dyskursie badacz aktywnie uczestniczy 22 .

2. Studia przypadku (Case Study Research, CSR) - to podejście koncentruje się na analizie indywidualnych przypadków występujących w obrębie społeczeństwa, $\mathrm{w}$ danym

19 The SAGE Handbook..., cyt. za: M. Gorzko, Teoria ugruntowana..., s. 11. Gorzko szczególowo omawia koncepcję obu autorów i rozważa wnikliwie poszczególne kategorie wymagające rozstrzygnięcia na gruncie metodologii teorii ugruntowanej

20 B.G. Glaser, A.L. Strauss A.L., Odkrywanie teorii ugruntowanej...

21 K. Charmaz, Constructing Grounded Theory. A Practical Guide Through Qualitative Analysis, London 2006 (wyd. pol. Teoria ugruntowana. Praktyczny przewodnik po analizie jakościowej, przeł. B. Komorowska, red. nauk. K. Konecki, Warszawa 2009, Metodologia).

22 Tamże. 
typie reżimu politycznego, w ramach partii politycznych, w obrębie grupy społecznej, dotyczy osoby lub konkretnego wydarzenia. W analizach dotyczących studiów przypadku podejmuje się wysiłek analityczny mający na celu zrozumienie i ukazanie przyczyn zaistnienia pojedynczego przypadku w ramach struktury, dynamiki i kontekstu, w obrębie którego zachodzi. Informacje dotyczącego badanego, konkretnego przypadku mogą być zbierane przy użyciu metod ilościowych (kwantytatywnych) i jakościowych (kwalitatywnych) lub kombinacji obu metod. Pozwala to na stosowanie do analizy wielu podejść, np. antropologicznego, socjologicznego, historycznego, politologicznego, ekonomicznego i in. Celem prowadzonych studiów przypadku jest testowanie przyjętych do badań założeń teoretycznych lub indukcyjne inspirowanie procesu tworzenia teorii. Analiza prowadzona na poziomie studium przypadku może stanowić punkt wyjścia do podjęcia bardziej pogłębionych studiów o charakterze porównawczym.

3. Badania sondażowe/badania opinii publicznej - należą od kilkunastu lat do najczęściej prowadzonych badań na gruncie nauk społecznych. Nie oznacza to, że ten rodzaj badań należy uznać za najbardziej wartościowy od strony metodologicznej. Tak nie jest. Badania te mają głównie charakter wyjściowy, sygnalizujący nowe problemy, których pełniejsze rozpoznanie wymagać będzie zastosowania - na poziomie badań pogłębionych - bardziej zaawansowanych instrumentów badawczych. Przyjmuje się, że badania tego rodzaju mają na celu zrozumienie i poznanie świata wokół nas. $Z$ tego względu studiowanie opinii publicznej i zachowań jednostkowych może być użyteczne do analizy problemów edukacyjnych, zdrowia, rozwoju regionalnego, międzynarodowego, politycznego i in. Sondaże dotyczące kwestii ekonomicznych, społecznych i politycznych pozwalają badaczom na śledzenie dynamiki społecznych wartości, zachowań, postaw itp. Wyzwania natury metodologicznej w badaniach typu survey/badaniach opinii publicznej dotyczą dwóch podstawowych kwestii: „jak badać?” oraz „jak analizować dane zebrane w ten sposób?". W obu podejściach występuje otwarcie na nowe inspiracje natury metodologicznej.

4. Badanie tekstu, kontekstu, analiza dyskursywna - to - jak dotąd - w niewielkim stopniu wykorzystywane podejście metodologiczne w badaniach prowadzonych przez politologów. Często sięgają po nie badacze mediów i dokonują wielu interesujących poznawczo ustaleń, począwszy od prac empirycznych podjętych z inspiracji i dla potrzeb rządu Stanów Zjednoczonych w okresie II wojny światowej przez amerykańskiego badacza Bernarda Berelsona, twórcę analizy zawartości i analizy treści. Następnym, bardziej zaawansowanym etapem metodologicznego rozwinięcia tego podejścia badawczego było opracowanie założeń analizy dyskursywnej przez takich badaczy, jak: Norman Fairclough, Teun van Dijk, Pierre Bourdieu i in. To podejście metodologiczne pozwala na prowadzenie badań o charakterze ilościowym i jakościowym, a w ostatnich kilkunastu latach - w oparciu o elektroniczne przetwarzanie informacji (EPI). Szczególnie zwraca uwagę potencjał poznawczy analizy dyskursywnej, który pozwala na pogłębioną analizę kontekstu toczącego się w sferze publicznej dyskursu politycznego, kulturowego, społecznego, artystycznego i in.

5. Analiza porównawcza i metody porównawcze - zainteresowanie badaniami o charakterze porównawczym datuje się od dość dawna, właściwie od początków po- 
wstania socjologii jako dyscypliny naukowej powstałej w XIX w. na gruncie nauk społecznych. Za jej twórcę uważa się Emila Durkheima - francuskiego socjologa, twórcę empirycznego podejścia do badania rzeczywistości społecznej. Niemniej należy stwierdzić, że ilość realizowanych badań o charakterze porównawczym, jak i stosowane metody do prowadzenia badań o charakterze porównawczym nie są satysfakcjonujące, natomiast wartość poznawcza płynąca $\mathrm{z}$ badań o charakterze porównawczym nie jest przez nikogo z badaczy kwestionowana. Pytanie, jakie rodzi się w związku z tym, jest następujące: dlaczego tak rzadko sięgamy do metody i analizy porównawczej, skoro są one tak wartościowe poznawczo, a preferujemy studia przypadku, najczęściej o charakterze deskryptywnym? To inspirujące wyzwanie dla badaczy w naukach politycznych i przydatne byłoby częstsze sięganie po nie.

\section{REFLEKSJE KOŃCOWE}

Przedstawione w powyższej analizie aktualne wyzwania metodologiczne i badawcze w naukach politycznych sygnalizują, że jest jeszcze wiele do zrobienia w tym zakresie. Bardziej pogłębione podejście i otwarcie metodologiczne nie powinno być postrzegane jako trudna do pokonania bariera poznawcza, dostępna tylko dla wtajemniczonych, doświadczonych specjalistów w metodologii badań naukowych. To możliwość, szerokie pole do inspiracji, w obrębie którego każdy badacz może wnieść wartościowy wkład, pomysłowość, nowe idee, które można przetestować i wyprowadzić z tych działań nowe, szerzej udokumentowane, głębiej osadzone teoretycznie wnioski. Czyli należy aktywniej podążać w tym kierunku, przyniesie to bowiem obiecujące rezultaty poznawcze, a rozbudowane podejście metodologiczne wspomoże proces poznawania złożonej rzeczywistości społecznej.

\section{BIBLIOGRAFIA}

Bundich-Verlag, [online] www.budrich-verlag.de.

Charmaz K., Constructing Grounded Theory. A Practical Guide Through Qualitative Analysis, London 2006 (wyd. pol. Teoria ugruntowana. Praktyczny przewodnik po analizie jakościowej, przeł. B. Komorowska, red. nauk. K. Konecki, Warszawa 2009, Metodologia).

Digital Democracy. Issues of Theory and Practice, red. K. Hacker, J. van Dijk, London 2000.

Dogan M., Political Science and the Other Social Sciences, [w:] A New Handbook of Political Science, red. R. Goodin, H.-D. Klingemann, Oxford 1996.

Easton D., The Political System. An Inquiry into the State of Political Science, New York 1953.

Glaser B.G., Strauss A.L., The Discovery of Grounded Theory. Strategies for Qualitative Research, Chicago 1967, Observations (wyd. pol. Odkrywanie teorii ugruntowanej. Strategie badania jakościowego, przeł. M. Gorzko, Kraków 2009, Wspótczesne Teorie Socjologiczne, 6).

Gorzko M., „Drugie pokolenie” teoretyków Grounded Theory, „Zeszyty Naukowe Uniwersytetu Szczecińskiego. Studia Sociologica” 2010, nr 20. 
Gorzko M., Procedury i emergencja. O metodologii klasycznych odmian teorii ugruntowanej, Szczecin 2008, Rozprawy i Studia Uniwersytetu Szczecinskiego, t. 693.

Gorzko M., Teoria ugruntowana jako „rodzina metod”?, „Opuscula Sociologica” 2013, nr 4.

Lasswell H., The Structure and Function of Communication in Society, [w:] The Communication

of Ideas. A Series of Addresses, red. L. Bryson, New York 1948, Religion and Civilization Series.

Lasswell H. i in., Language of Politics. Studies in Quantitative Semantics, New York 1949.

Lazarsfeld P., Berelson B., Gaudet H., The People's Choice. How the Voter Makes Up his Mind in a Presidential Campaign, New York 1944.

McLuhan M., Zrozumieć media. Przedtużenia cztowieka, przeł. N. Szczucka, Warszawa 2004.

Merriam Ch., Gosnell H., The American Party System. An Introduction to the Study of Political Parties, New York 1922.

Political Science in Central-East Europe. Diversity and Convergence, red. R. Eisfeld, L. Pal, Opladen-Farmington Hills 2010.

Power. State of the Art, red. M. Haugaard, K. Ryan, Opladen 2012.

RC 33 - The Study of Political Science as a Discipline, IPSA, [online] http://rc33.ipsa.org.

The SAGE Handbook of Grounded Theory, red. A. Bryant, K. Charmaz, Los Angeles-London 2007.

Strubing J., Research as Pragmatic-Solving: the Pragmatists Roots of Empirically-Grounded Theorizing, [w:] The SAGE Handbook of Grounded Theory, red. A. Bryant, K. Charmaz, Los Angeles-London 2007.

Trent J.E., Seeking a New Political Studies Paradigm, referat wygłoszony w ramach „International Workshop on Study and Research of Political Science in a Comparative Perspective", Mexico City, 7-8 XI 2013.

Trent J.E., Should Political Science be More Relevant? An Empirical and Critical Analysis of the Discipline, „European Political Science” 2011, Vol. 10, nr 2, [online] http://dx.doi. org/10.1057/eps.2010.65.

Wyzwania wobec nauk spotecznych u progu XXI wieku, oprac. A. Flis, przeł. B. Lessaer, Kraków 1999.

Dr hab. Teresa SASIŃSKA-KLAS, prof. UJ - socjolog i politolog, profesor nadzwyczajny w Instytucie Dziennikarstwa i Komunikacji Społecznej Uniwersytetu Jagiellońskiego. W latach 2004-2010 prezes Zarządu Głównego Polskiego Towarzystwa Nauk Politycznych. W 2009 r. wybrana na XXI Kongresie Światowym IPSA w Santiago (Chile) do Komitetu Wykonawczego Międzynarodowego Towarzystwa Nauk Politycznych (IPSA). W latach 2012-2014 wiceprezydent Międzynarodowego Towarzystwa Nauk Politycznych ds. Europy i Afryki. Zajmuje się zawodowo analizą relacji mediów i polityki, socjalizacją polityczną oraz teoretycznymi aspektami opinii publicznej. 